\title{
Childhood Pineal Parenchymal Cell Neoplasm
}

National Cancer Institute

\section{Source}

National Cancer Institute. Childhood Pineal Parenchymal Cell Neoplasm. NCI Thesaurus.

Code C115196.

A pineal parenchymal cell neoplasm that occurs during childhood. 